\title{
Penerapan GMP pada UKM Keripik SEMAT (Sehat dan Nikmat)
}

\section{Application of GMP in SME of SEMAT Chips (Healthy and Delicious)}

\author{
Dimas Bayu Pinandoyo, Asriadi Masnar \\ Teknik Kemasan Politeknik Negeri Media Kreatif \\ J. Srengseng Sawah Raya No.17, Jakarta Selatan, Daerah Khusus Ibukota Jakarta \\ dimas.pinandoyo@polimedia.ac.id
}

\begin{abstract}
Abstrak
Keripik Semat Desa Tenjo merupakan Usaha Kecil Menengah (UKM) yang telah memiliki PIRT dengan nomor 2153201010561-22. Meski demikian UKM ini masih memerlukan prosedur-prosedur untuk memenuhi persyaratan-persyaratan kualitas pangan yang baik. Penelitian ini bertujuan untuk menganalisis masalah keterbatasan UKM dalam memenuhi persyaratan-persyaratan kualitas pangan yang baik. Dalam penelitian ini permasalahan dianalisis dengan metode observasi, FGD, dan wawancara secara mendalam. Acuan GMP yang dirujuk merupakan standar yang dipakai oleh Food Safety Center of Manitoba (2018). Penerapan Good Manufacturing Practice (GMP) di UKM Keripik Tenjo telah memenuhi syarat-syarat CPPB-IRT pada level 4 (PIRT). Namun diperlukan kontrol yang lebih baik pada peralatan, peningkatan nilai praktek personal, penerapan prosedur penjagaan kebersihan bahan, kontrol lingkungan, pengontrolan penggorengan, pengemasan, dan storage.
\end{abstract}

Kata kunci: GMP; keamanan pangan; keripik; kualitas pangan; UKM

\begin{abstract}
Semat Chips Tenjo Village is a Small and Medium Enterprises (SMEs) that already has PIRT with number 2153201010561-22. However sets of procedures still needed to ensure the good qulity standards sets by government.This study aims to reveal the problem of the limitations of SMEs in fulfilling the requirements of good quality food. In this study the problem was analyzed by the method of observation, FGD, and in-depth interviews. The referred Good Manufacturing Practice (GMP) reference is the standard used by the Food Safety Center of Manitoba (2018). The application of GMP in Tenjo Chips SMEs has fulfilled the CPPB-IRT requirements at level 4 (PIRT). However, better control is needed on equipment, the value of personal practice, implementation of cleaning procedures for material hygiene, environmental control, frying control, proper packaging, and storage.
\end{abstract}

Keywords: chips; food security; food quality; GMP; SMEs

\section{PENDAHULUAN}

Peningkatan standar kualitas dan keamanan pangan merupakan syarat mutlak peningkatan perkembangan UKM pangan. Saat ini menurut data dari BPOM tahun 2017, industri makan rumah tangga berkontribusi sekitar 49,5\% terhadap keracunan pangan di Indonesia. Jaminan mutu dan keamanan produk tidak hanya 
penting untuk melindungi kemanan konsumen domestik, namun juga penting untuk meningkatkan daerah edar dari makanan yang diproduksi (Dewi, 2017). Hubeis dan Najib (2014) menyebutkan, bahwa mengaplikasikan GMP dan standarstandar kualitas pangan, dapat meningkatkan ketahanan dan pemasaran produk pangan UKM.UKM Keripik SEMAT Desa Tenjo merupakan salah satu program pemberdayaan masyarakat yang diprakarsai oleh NGO PKPU Human Initiative. Program ini dimulai pada tahun 2014.

Pada tahun 2015, 1,5 juta anak setidaknya meninggal dikarenakan keracunan makanan (WHO, 2015). Di Asia Tenggara, setiap tahunnya diperkirakan 175.000 kematian disebabkan oleh Food Borne Disease (WHO, 2015). Di Indonesia, pada tahun 2016 setidaknya 5.673 terpapar keracunan pangan, 3.351 diantaranya sakit, dan 7 diantaranya meninggal setiap tahunnya (BPOM, 2016). Di Jawa Barat pun kesadaran pengurusan PIRT masih rendah. Baru 33,95\% UMKM pangan saja yang terdaftar PIRT (Yulianti dan Mustarichie, 2018).

UU No. 18 tahun 2012 tentang pangan berfungsi untuk memberikan jaminan kepada masyarakat guna mendapatkan makanan atau minuman yang higienis yang tidak merugikan konsumen. Permasalahan terbesar dalam UKM kecil dan menengah pada umumnya adalah minimnya sumber daya, kondisi sarana prasarana kerja yang kurang diperhatikan, Tata letak ruang yang belum sesuai dengan urutan proses, Fasilitas kerja yang belum memadai, Kondisi Higiene karyawan, Kualitas dan keamanan bahan baku, Kondisi sanitasi lingkungan di sekitar UKM sehingga sangat sulit untuk memenuhi standar-standar kualitas pangan yang baik secara stabil. Standar higienitas yang belum terpenuhi masih berupa standar dasar dari penerapan Good Manufacturing Practice (GMP).

Penelitian ini penting untuk memastikan makanan yang dihasilkan memenuhi kriteria makanan sehat, bermutu, dan layak dikonsumsi oleh masyarakat. Lebih lanjut penelitian ini dapat berfungsi untuk meningkatkan standar kualitas sesuai dengan keterbatasan sumber daya yang dimiliki oleh UKM. Penelitian ini bertujuan untuk menganalisis masalah keterbatasan UKM dalam memenuhi persyaratan-persyaratan kualitas pangan yang baik dan memberikan usulan tindakan yang harus dilakukan.

\section{METODOLOGI}

Penelitian dilakukan di tempat produksi keripik Semat Desa Tenjo yang beralamat di Rumah Produksi SEMAT, kampung Leuweung Gede, Desa Tenjo, Kecamatan Tenjo, Kabupaten Bogor, Jawa Barat sepanjang bulan Mei tahun 2019. Penelitian dilakukan dalam beberapa tahap yaitu:

a. Pemetaan Sarana dan Prasarana Produksi

Pemetaan dilakukan dengan metode observasi dan FGD. Observasi dilakukan dengan mengambil referensi dari metode yang dilakukan oleh Hasnan dkk (2014). Sesuai dengan standar GMP dan HACCP, observasi dilakukan dari proses pengambilan bahan baku, proses produksi yang meliputi pemilihan bahan, pencucian, pengupasan, pengirisan, penggorengan, dan pembumbuan, pengeringan, dan yang terakhir adalah proses pengemasan. Data yang terkumpul dari proses observasi kemudian dijadikan rujukan untuk penentuan tindak lanjut yang perlu dilakukan. FGD dan wawancara mendalam dilakukan kepada Annisa Khurrohmah sebagai koordinatir tim pelaksana program 
pendampingan masyarakat PKPU Human Intiative di Desa Tenjo dan Asri Permatasari sebagai Manajer Pemberdayaan PKPU Human Initiative, dan Bu Een Sunengsih sebagai koordinator usaha keripik.

b. Penentuan Tindak Lanjut

Penentuan tindak lanjut mengacu pada prinsip-prinsip yang dianut oleh Food Safety Center of Manitoba (2018) dengan mengutamakan 8 prinsip dasar GMP. Premis yang digunakan adalah kontrol lingkungan, penerapan nilai praktek yang diperbarui difokuskan pada nilai praktek personal, distribusi dikontrol dengan sistem inspeksi, memonitor adanya hama, manajemen sanitasi, perawatan peralatan, penerapan pengarsipan untuk menerapkan prinsip "recall and traceability", serta pemastian kemanan dan kesehatan air yang digunakan.

c. Penyusunan Standar GMP

Standar GMP dibuat dengan memegang prinsip kontrol ideal dan pemberian opsi kontrol minimal.

\section{HASIL DAN PEMBAHASAN}

a. Pemetaan Sarana dan Prasarana Produksi

Dari observasi dan FGD mengenai sarana dan prasarana di tempat produksi Keripik Semat Tenjo, diperoleh hasil sebagai berikut,

Tabel 1. Hasil Observasi dan FGD Mengenai Sarana dan Prasarana di Tempat Produksi Keripik Semat Tenjo

\begin{tabular}{|c|c|}
\hline Parameter Pengamatan & Kondisi \\
\hline Proses pengambilan bahan baku & $\begin{array}{l}\text { - } \text { Belum satu pintu } \\
\text { - } \text { Belum ada alur bahan baku yang } \\
\text { jelas } \\
\text { - } \begin{array}{l}\text { Belum menerapkan prinsip } \\
\text { sanitasi }\end{array}\end{array}$ \\
\hline Proses produksi & $\begin{array}{l}\text { - Pemilihan bahan belum } \\
\text { menerapkan kriteria bahan } \\
\text { terstandar untuk digunakan } \\
\text { dalam proses produksi } \\
\text { - Pencucian baru ketika akan } \\
\text { dimasak saja } \\
\text { - Pengupasan dan pengirisan belum } \\
\text { menerapkan standar keamanan } \\
\text { pekerja } \\
\text { Penggorengan belum memiliki } \\
\text { acuan standar panas dan } \\
\text { keamanan minyak goreng yang } \\
\text { boleh dipakai secara berulang } \\
\text { Penggorengan belum menerapkan } \\
\text { standar keamanan pekerja } \\
\text { Pembumbuan masih dilakukan } \\
\text { dengan wadah terbuka sehingga } \\
\text { membuka resiko untuk cemaran } \\
\text { mikrobia diangan } \\
\text { Pengeringan dilakukan dengan } \\
\text { alat yang belum dikontrol } \\
\text { pembersihannya secara tepat }\end{array}$ \\
\hline
\end{tabular}




\begin{tabular}{ccl}
\hline & Distribusi dari satu tempat \\
& $\begin{array}{l}\text { pemrosesan ke tempat yang lain } \\
\text { dengan wadah terbuka }\end{array}$ \\
\hline Pengemasan & $\begin{array}{l}\text { Masih belum menerapkan prinsip } \\
\text { higienitas tempat, pekerja, alat, } \\
\text { dan bahan dengan optimal }\end{array}$ \\
\hline
\end{tabular}

Dari hasil observasi dan FGD diketahui bahwa proses input bahan mentah masih belum terkoordinir. Terkadang bahan mentah ditumpuk di belakang rumah produksi begitu saja. Pada lain waktu ditinggal di dapur warga demi keamanan, dan sebagainya. Desain alur bahan juga belum dibuat. Desain alur dan kontrol bahan baku yang masuk penting untuk dilakukan untuk meminimalisir microbial load yang masuk ke dalam proses produksi. Dalam UKM ini, proses sterilisasi masih tergantung pada proses pemanasan yaitu melalui proses penggorengan. Pengontrolan bagaimana bahan itu masuk, jalur yang dilalui oleh bahan, dan dimana bahan dari tiap proses dikumpulkan sangat penting untuk menghindari cross-contamination. Kenedy et.al. (2011) menyebutkan bahwa pada level usaha rumah tangga, $21 \%$ kerusakan kualitas pangan disebabkan oleh cross-contamination. FAO (2017) melalui buku "Food Handler Manual Instructor" menyebutkan bahwa dalam skala industri rumah tangga, enteropathogenik E.coli merupakan prioritas mikrobia yang harus dihindari dalam ranah cross-contamination. Cara penanggulangan mikrobia penyebab cross-contamination ini kemudian dijadikan acuan dalam standar pencegahan kontaminasi mikrobia oleh Alum et al. (2016).

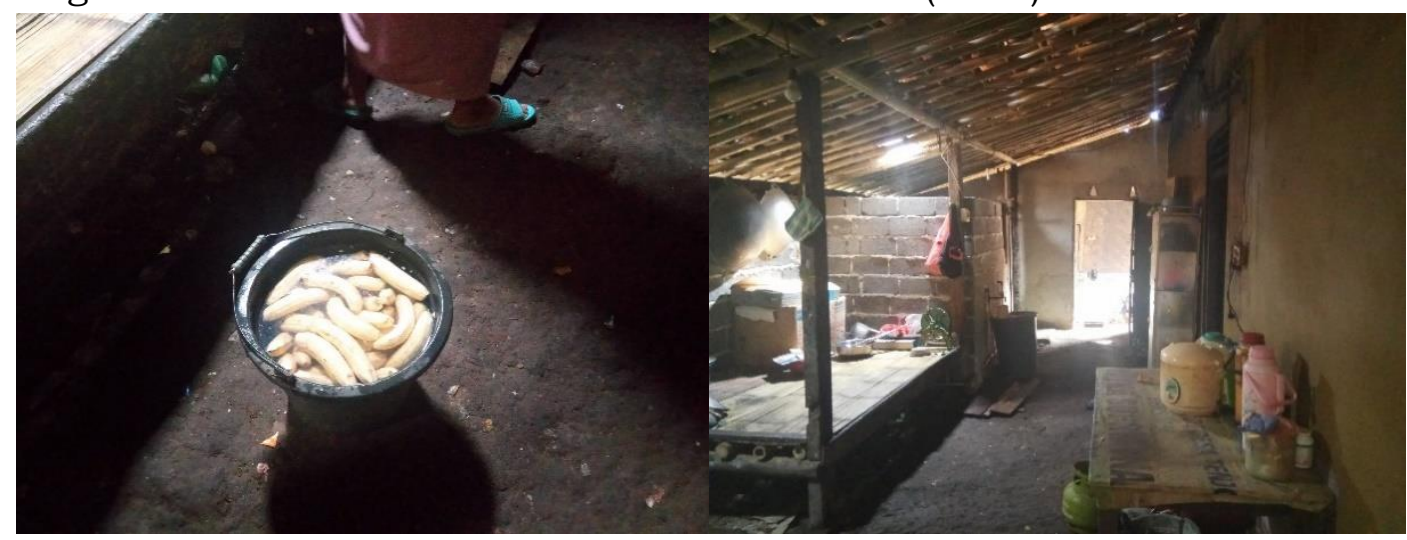

Gambar 1. Kondisi Bahan Masuk Saat Observasi: Bahan Masuk Diletakkan Di Dapur Warga

Dari hasil observasi dan FGD juga diketahui bahwa belum ada pembukuan darimana bahan tersebut diambil, bagaimana kualitasnya, dan apakah bahan tersebut ideal untuk produksi atau tidak. Bahan yang digunakan pada UKM Keripik Semat ada tiga yaitu pisang, singkong, dan talas. Pengontrolan bagaimana bahan-bahan tersebut masuk dan disimpan sebelum diolah sangat penting untuk memastikan kualitas hasil yang homogen. Seperti terlihat di Gambar 1, Bahan terlihat diletakkan begitu saja di dapur warga yang masih berlantai tanah. Tentunya hal ini membuka resiko yang besar untuk kontaminasi mikrobia. Prosesnya juga belum menerapkan konsep sanitasi. Warga belum mencuci tangan dan kaki ketika hendak memulai proses pemasokan bahan mentah. Semua proses yang melibatkan air dilakukan di satu tempat yang sama, yaitu di kamar mandi 


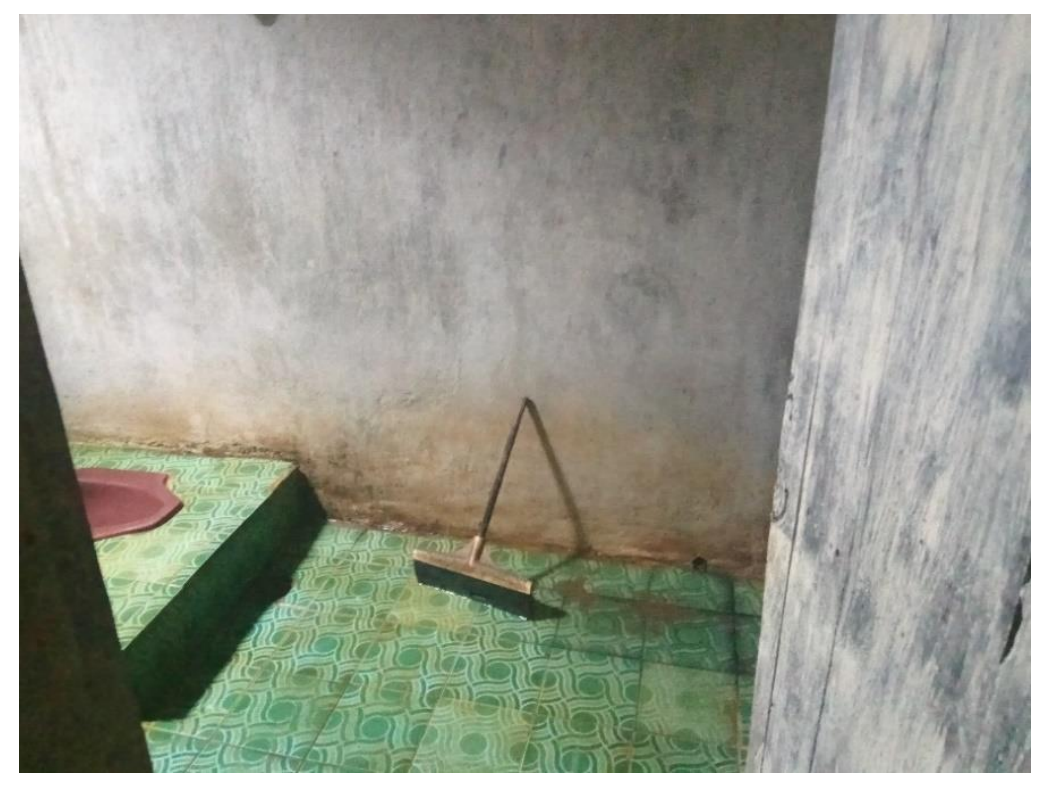

Gambar 2. Kondisi Kamar Mandi Tempat Pencucian

Proses sterilisasi sangat tergantung pada perlakuan panas yaitu penggorengan. Sayangnya kontrol suhu penggorengan belum terstandar. Yadav (2018) menyebutkan bahwa suhu yang tidak terkontrol bisa menyebabkan kerusakan minyak yang dapat menghasilkan senyawa kimia berbahaya bagi tubuh. Cuihua (2014) menyusun sebuah desain dapur terpusat untuk menghindari kerusakan dan bahaya-bahaya yang disebabkan dalam proses penggorengan.

Pasca perlakuan panas, proses pembumbuan dan pembungkusan juga masih dilakukan di tempat terbuka dan alat-alatnya masih belum dikontrol waktu pembersihannya. Pembersihan yang tidak terkontrol dan minimnya proteksi sesudah pasca perlakuan panas sangat memungkinkan re-kontaminasi terutama oleh hama, debu, ataupun mikrobia. American Spice Trade Association dalam bukunya mengenai petunjuk HACCP dalam sistem pembumbuan (2014) menyebutkan bahwa sistem pembumbuan yang tidak terkontrol kebersihannya sangat berisiko kontaminsai mikrobia dan fisik, terutama yang disebabkan oleh hama dan vektor lainnya. Codex Alimentarius edisi revisi 2014 menstandarkan bahwa pembumbuan sebisa mungkin dilakukan di tempat yang tertutup, terlindungi, sedemikian rupa sehingga terlindungi dari kontaminasi dari manusia, hewan, dan limbah rumah tangga, industri, maupun pertanian.

b. Penentuan Tindak Lanjut

Tindak lanjut dari hasil observasi dan FGD diterapkan dengan menggunakan 8 prinsip GMP yang diacu oleh Food Safety Center of Manitoba (2018) terangkum dalam table 2.

GMP di Indonesia dikemas dalam suatu perundangan yaitu PP No. 28 Tahun 2004 mengenai Cara Produksi Pangan yang Baik (CPPB). Dalam perundangan ini, GMP diartikan sebagai cara produksi yang memperhatikan aspek keamanan pangan yaitu,

1. Mencegah tercemarnya pangan oleh cemaran biologis, kimia, dan benda lain yang dapat mengganggu, merugikan, dan membahayakan kesehatan.

2. Memastikan atau mencegah hidupnya jasad renik pathogen dan mengurangi jumlah jasad renik lainnya. 
3. Mengendalikan proses diantaranya pemilihan bahan baku, penggunaan bahan tambahan pangan, pengolahan, penyimpanan, pengemmasan, dan pengangkutan

Tabel 2. Daftar Tindak Lanjut yang Diambil Berdasarkan Hasil Observasi dan FGD

\begin{tabular}{|c|c|c|}
\hline Prinsip & $\begin{array}{c}\text { Kondisi Permasalahan } \\
\text { yang Ditemukan }\end{array}$ & $\begin{array}{l}\text { Tindak Lanjut yang } \\
\text { Dilakukan }\end{array}$ \\
\hline $\begin{array}{l}\text { Kontrol } \\
\text { Lingkungan }\end{array}$ & $\begin{array}{l}\text { Proses pengambilan } \\
\text { bahan yang: } \\
\text { - Belum satu pintu } \\
\text { - Belum ada alur bahan } \\
\text { baku yang jelas } \\
\text { - Belum menerapkan } \\
\text { prinsip sanitasi }\end{array}$ & $\begin{array}{ll} & \begin{array}{l}\text { Denah Tempat Usaha } \\
\text { dengan alur kerja satu }\end{array} \\
\text { pintu dibuat } \\
\text { - } & \text { Alur Proses Produksi } \\
\text { dibuat dan dijalankan } \\
\text { - } & \text { Jadwal Piket Pembersihan } \\
\text { Ruangan dibuat } \\
\text { - } & \text { Tempat Pencucian dan } \\
& \text { Sumber Air direlokasi }\end{array}$ \\
\hline $\begin{array}{l}\text { Penerapan } \\
\text { Nilai Praktek } \\
\text { Personal }\end{array}$ & $\begin{array}{l}\text { Proses produksi yang: } \\
\text { - Menerapkan pencucian } \\
\text { ketika akan dimasak } \\
\text { saja } \\
\text { - Belum menerapkan } \\
\text { standar keamanan } \\
\text { pekerja dalam proses } \\
\text { pengupasan, } \\
\text { pengirisan, dan } \\
\text { penggorengan } \\
\text { Proses pengemasan yang: } \\
\text { Masih belum } \\
\text { menerapkan prinsip } \\
\text { higienitas pekerja,alat, } \\
\text { dan bahan }\end{array}$ & $\begin{array}{ll}\text { - } & \text { Standar sanitasi pekerja } \\
\text { diterapkan } \\
\text { - } & \text { Standar minimal } \\
\text { keselamatan kerja } \\
\text { diterapkan }\end{array}$ \\
\hline $\begin{array}{l}\text { Kontrol } \\
\text { Distribusi }\end{array}$ & $\begin{array}{l}\text { Proses pengambilan } \\
\text { bahan baku yang : } \\
\text { - Belum ada alur bahan } \\
\text { baku yang jelas } \\
\text { Proses produksi yang : } \\
\text { - Belum menerapkan } \\
\text { kriteria bahan } \\
\text { terstandar untuk } \\
\text { digunakan dalam } \\
\text { proses produksi } \\
\text { - Distribusi dari satu } \\
\text { tempat pemrosesan ke } \\
\text { tempat yang lain } \\
\text { dengan wadah terbuka } \\
\text { - Penerapan prinsip } \\
\text { "recall and traceability" }\end{array}$ & $\begin{array}{l}\text { - Sistem transfer dari satu } \\
\text { tempat pemrosesan ke } \\
\text { tempat yang lain dengan } \\
\text { Sistem Tertutup } \\
\text { diterapkan } \\
\text { - } \\
\text { Sistem pembukuan di } \\
\text { setiap tahap Pemrosesan } \\
\text { diaplikasikan }\end{array}$ \\
\hline
\end{tabular}




\begin{tabular}{|c|c|c|}
\hline $\begin{array}{l}\text { Inspeksi } \\
\text { Hama }\end{array}$ & $\begin{array}{l}\text { Proses produksi yang: } \\
\text { - Masih belum } \\
\text { menerapkan prinsip } \\
\text { higienitas tempat, } \\
\text { pekerja,alat, dan bahan } \\
\text { dengan optimal }\end{array}$ & $\begin{array}{l}\text { - Jadwal Piket Kebersihan } \\
\text { disusun }\end{array}$ \\
\hline $\begin{array}{l}\text { Pemastian } \\
\text { Kemanan } \\
\text { dan } \\
\text { Kesehatan } \\
\text { Air yang } \\
\text { Digunakan }\end{array}$ & $\begin{array}{ll}\text { - } & \text { Pengoptimalan } \\
\text { penerapan prinsip } \\
\text { sanitasi } \\
\text { - } \\
\text { Memastikan tidak ada } \\
\text { genangan air }\end{array}$ & $\begin{array}{l}\text { Tempat pencucian } \\
\text { bahan, tangan, kaki, dan } \\
\text { pemrosesan di tempat } \\
\text { yang masing-masing } \\
\text { terpisah dibuat dan } \\
\text { diaplikasikan }\end{array}$ \\
\hline $\begin{array}{l}\text { Kontrol } \\
\text { Pengemasan }\end{array}$ & $\begin{array}{l}\text { Masih belum } \\
\text { menerapkan prinsip } \\
\text { higienitas tempat, } \\
\text { pekerja, alat, dan } \\
\text { bahan dengan optimal }\end{array}$ & $\begin{array}{l}\text { Kontrol Hygiene dan } \\
\text { pengujian kualitas } \\
\text { kemasan diterapkan }\end{array}$ \\
\hline
\end{tabular}

Pemerintah melalui PERMENPRIN No. 75 Tahun 2010 mensyaratkan 18 aspek yang harus diperhatikan dalam penyusunan GMP yaitu (1) Lokasi; (2) Bangunan; (3) Fasilitas Sanitasi; (4) Mesin dan Peralatan; (5) Bahan; (6) Pengawasan Proses; (7) Produk akhir; (8) Laboratorium; (9) Karyawan; (10) Pengemas; (11) Label dan Keterangan Produk; (12) Penyimpanan; (13) Pemeliharaan dan Program Sanitasi; (14) Pengangkutan; (15) Dokumentasi dan Pencatatan; (16) Pelatihan; (17) Penarikan Produk; (18) Pelaksanaan Pedoman. Sayangnya pedoman ini masih terlalu sulit untuk diterapkan dalam UKM. Karenanya digunakan Acuan dari Food Safety Center of Manitoba (2018) dalam pelaksanaan kegiatan yang harus dilakukan. Dalam penetuan tindakan yang harus diterapkan di UKM Keripik Semat Desa Tenjo, sumber daya yang tersedia dirasa cukup untuk memenuhi standar yang diterapkan oleh Food Safety Center of Manitoba tersebut. Kontrol lingkungan meliputi kontrol lokasi, desain dan konstruksi, peralatan dan suplai air. Kontrol lingkungan sangat penting dan berkorelasi terhadap daya saing usaha kecil. Chukwu (2009) menyebutkan bahwa selain kontrol dan perencanaan usaha, kontrol lingkungan ternyata berhubungan erat dengan kinerja perusahaan. Sutton (2010) menyebutkan bahwa kontrol lingkungan yang rutin merupakan aspek penting dalam keberhasilan penerapan GMP dalam suatu usaha. Penerapan kontrol lingkungan merupakan kunci keberhasilan GMP pada produksi obat-obatan parenteral (Ingle et al., 2010). Kontrol lingkungan yang efisien ternyata tidak hanya berdampak pada GMP tapi juga performa bisnis perusahaan (Yang, 2011).

Penerapan nilai praktek personal yang diterapkan untuk menyusun pada UKM Semat desa Tenjo meliputi kesehatan personal, higienitas pribadi, dan kontrol akses pribadi yang terarah. FAO (2017) dalam buku Food Handler Manual menyebutkan bahwa kondisi kesehatan yang prima dari pekerja merupakan syarat mutlak untuk menjaga agar proses produksi berlangsung secara aman dan terkendali. Pekerja yang sakit memiliki resiko untuk menyebarkan allergen ataupun kuman penyebab penyakitnya ke dalam produk makanan. Beberapa toleransi diberikan namun larangan mutlak diberlakukan bagi pekerja yang mengalami sakit yang berhubungan dengan pernafasan (seperti batuk, influenza, 
dsb), sakit perut (diare), luka serius (terutama luka besar dan koreng), serta penyakit-penyakit infeksi lainnya. Higienitas minimal bagi UKM menurut buku tersebut adalah kebiasaan mencuci tangan dengan sabun sebelum dan sesudah melakukan pekerjaan, mandi sebelum datang bekerja, dan menjaga kebersihan kuku. Penjagaan alur dilakukan dengan membagi pekerja ke dalam bagianbagian atau proses produksi tertentu. Untuk menghindari cross contamination, idealnya pekerja di satu bagian proses tidak keluar masuk ke bagian yang lainnya. Hubeis et al., (2014) menyebutkan bahwa pengetahuan mengenai HACCP dan GMP sangat penting untuk strategi pengembangan umkm pangan yang berdaya saing di Indonesia. Mukantwali et al. (2013) menyebutkan bahwa pada UKM pengelolaan nanas di Rwanda, hampir semua sampel yang diteliti belum memenuhi standar higienitas personal.

c. Penyusunan Standar GMP

Denah usaha dan penetapan alur distribusi pada UKM Keripik Semat Desa Tenjo adalah sebagai berikut,

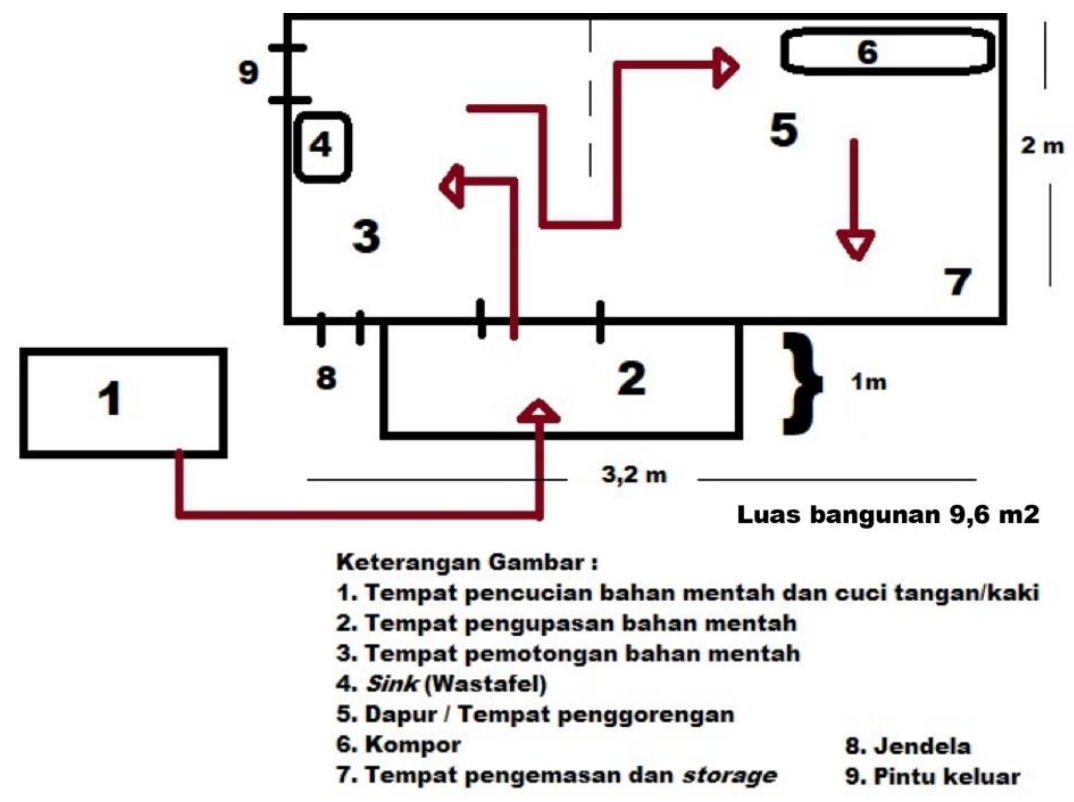

Gambar 3. Skema Tempat Usaha Keripik Semat Desa Tenjo

Luas bangunan 9,6 meter persegi. Desain ini dibangun untuk memudahkan pekerja dan pengontrol dalam menjaga alur produksi dan menetapkan alur recall and control dalam produksi. Pekerja mencuci tangan dan kaki di zona pencucian (1) untuk selanjutnya bekerja pada proses pengerjaan masing-masing. Setiap proses pengerjaan dikontrol oleh satu orang pengawas. Desain ini juga digunakan untuk mempermudah alur pengontrolan kebersihan tempat kerja, alat, bahan, dan produk. Dengan pengontrolan ini diharapkan jika diadakan inspeksi dari Dinkes maupun BPOM, dalam ranah ruang produksi, keripik Semat Desa Tenjo dapat memperoleh minimal poin minimal 90\% (sangat ideal). Dengan adanya alur dan sistem pengawasan yang baik, diharapkan UKM Keripik Semat Desa Tenjo dapat terus terkontrol secara mandiri. Sistem pengawasan dilakukan setiap minggu dengan jadwal koordinator piket sebagai berikut, 
Tabel 3. Jadwal Koordinator Piket Keripik Semat Desa Tenjo

\begin{tabular}{ccc}
\hline Nama Koordinator & \multicolumn{2}{c}{ Parameter } \\
\cline { 2 - 3 } Pengontrol & Hari Piket & Peralatan \\
\hline Bu Een & Selasa Minggu 1 & Baskom, Pisau, dll \\
\hline Bu Meli & Selasa Minggu 2 & Penggorengan \\
\hline Bu Sanah & Selasa Minggu 3 & Pengering \\
\hline Teh Ipit & Selasa Minggu 4 & Alat packing \\
\hline
\end{tabular}

Permasalahan yang umum ditemui dalam pembersihan adalah kurang bersihnya alat. Selain bertugas mengkoordinir kebersihan tempat, setiap minggunya dilakukan pengecekan peralatan secara rutin oleh masing-masing koordinator untuk memastikan bahwa peralatan yang dipakai senantiasa dalam kondisi bersih. Anggraini dan Yudhastuti (2014) dalam penelitiannya tentang penerapan GMP pada keripik Teripang menyebutkan bahwa ruang dan sarana produksi merupakan penghalang utama diperolehnya skor optimal dari pengawas pangan Kabupaten/ Kota. UKM Pangan umumnya banyak yang masih dalam kondisi serius hingga kritis. Dewi (2017) menyebutkan bahwa pada produksi Kerupuk Ikan Tengiri di Cilacap, masih banyak ditemui sarana dan fasilitas yang tidak sesuai dengan persyaratan Cara Produksi Pangan yang Baik (CPPB). Sarana dan fasilitas produksi yang paling banyak ketidaksesuaiannya adalah Sarana Cuci Tangan, diikuti oleh minimnya penggunaan Alat Pelindung Diri (APD) pada karyawan, kemudian yang terakhir adalah tidak adanya bagan alir proses produksi. Hanif (2017) dalam skripsinya mengenai implementasi CPPB P-IRT pada UKM pangan di Pemalang menyebutkan bahwa sarana dan fasilitas produksi merupakan salah satu faktor yang menyebabkan minimnya implementasi peraturan pemerintah mengenai CPPB P-IRT.

Pemerintah melalui Peraturan Kepala Badan Pengawas Obat dan Makanan Republik Indonesia Nomor HK.03.1.23.04.12.2207 Tahun 2012 tentang Tata Cara Pemeriksaan Sarana Produksi Pangan Industri Rumah Tangga mensyaratkan pengecekan terhadap hal-hal berikut,

- Lokasi dan Lingkungan

Produksi;

- Bangunan dan Fasilitas;

- Peralatan Produksi;

- Suplai Air atau Sarana

Penyediaan Air;

- Fasilitas dan Kegiatan Higiene dan Sanitasi;

- Kesehatan dan Higiene Karyawan;
- Pemeliharaan dan Program Higiene Sanitasi;

- Penyimpanan;

- Pengendalian Proses;

- Pelabelan Pangan;

- Pengawasan oleh Penanggungjawab;

- Penarikan Produk;

- Pencatatan dan Dokumentasi;

- Pelatihan Karyawan;

Kebersihan dan keamanan lingkungan produksi, bangunan, dan fasilitas dikontrol melalui jadwal piket. Peralatan dibersihkan setiap kali habis pakai, sedangkan kebersihan tempat kerja dilakukan setiap hari sampai minimal seminggu sekali. Selalu dipastikan bahwa alat bebas dari debu, kotoran, dan sebisa mungkin kuman. Nuraida (2008) menyebutkan kondisi higienitas, kebersihan, dan keamanan sarana produksi di UKM Pangan Indonesia masih sangat rendah. Ningsih (2014), menyebutkan, kebersihan dan keamanan pangan di UKM Pangan di sekitar SDN Kota Samarinda meningkat setelah 
penyuluhan dengan hasil uji sampel menemukan kadar E. coli setelah penyuluhan hanya berkisar $4,17 \%$ saja.

Untuk memastikan hal tersebut dipenuhi, diperlakukan SOP sebagai berikut :

Tabel 4. SOP Standar yang Diterapkan Di UKM Keripik Semat Desa Tenjo

\begin{tabular}{|c|c|c|}
\hline \multirow{2}{*}{ Parameter } & \multicolumn{2}{|c|}{ SOP } \\
\hline & Ideal & Minimal \\
\hline $\begin{array}{l}\text { Peralatan Produksi (Pisau, } \\
\text { baskom, alat pengupas } \\
\text { bahan baku, telenan, alat } \\
\text { masak, pengering) }\end{array}$ & $\begin{array}{l}\text { Cuci setelah pakai, } \\
\text { keringkan. }\end{array}$ & Cuci setelah pakai \\
\hline \multirow{5}{*}{ Nilai Praktek Personal } & $\begin{array}{l}\text { Larangan bekerja bagi } \\
\text { karyawan yang sakit }\end{array}$ & $\begin{array}{l}\text { Karyawan sakit } \\
\text { masih boleh bekerja } \\
\text { selama bukan } \\
\text { penyakit menular }\end{array}$ \\
\hline & $\begin{array}{l}\text { Kewajiban mencuci } \\
\text { tangan dan kaki sebelum } \\
\text { masuk area kerja di area } \\
\text { cuci tangan dengan sabun } \\
\text { merek Yuri }\end{array}$ & $\begin{array}{l}\text { Kewajiban mencuci } \\
\text { tangan dan kaki } \\
\text { sebelum masuk area } \\
\text { kerja di area cuci } \\
\text { tangan dengan sabun } \\
\text { merek Yuri } \\
\text { pengenceran } 50 \%\end{array}$ \\
\hline & $\begin{array}{l}\text { MCK dilakukan di jamban } \\
\text { di luar area kerja }\end{array}$ & $\begin{array}{l}\text { MCK di jamban UKM } \\
\text { selama dijaga } \\
\text { kebersihan terjaga }\end{array}$ \\
\hline & $\begin{array}{l}\text { Kewajiban memakai } \\
\text { peralatan standar } \\
\text { bekerja/Alat Pelindung } \\
\text { Diri/ APD (Celemek, } \\
\text { pelindung kepala, masker, } \\
\text { pelindung tangan) }\end{array}$ & $\begin{array}{l}\text { Kewajiban memakai } \\
\text { celemek, selalu cuci } \\
\text { tangan sebelum } \\
\text { melakukan sesuatu, } \\
\text { menggunakan } \\
\text { jilbab/kerudung yang } \\
\text { bersih }\end{array}$ \\
\hline & $\begin{array}{l}\text { Pemindahan ke kemasan } \\
\text { plastik besar (glondongan) } \\
\text { dan kemasan siap jual } \\
\text { (retail) dengan sarung } \\
\text { tangan dan dalam kondisi } \\
\text { bersih }\end{array}$ & $\begin{array}{l}\text { Pemindahan ke } \\
\text { kemasan glondongan } \\
\text { dan retail bebas, asal } \\
\text { pakaian dan kondisi } \\
\text { badan pekerja bersih } \\
\text { dan sudah cuci } \\
\text { tangan/kaki dengan } \\
\text { sabun }\end{array}$ \\
\hline $\begin{array}{l}\text { Pembersihan celemek dan } \\
\text { sarung tangan }\end{array}$ & Seminggu sekali & Sebulan sekali \\
\hline \multirow[b]{2}{*}{$\begin{array}{l}\text { Penerapan prosedur } \\
\text { penjagaan kebersihan } \\
\text { bahan }\end{array}$} & $\begin{array}{l}\text { Penerapan pencucian } \\
\text { bahan baku: Basuh-Usap- } \\
\text { Basuh sebelum dikupas }\end{array}$ & $\begin{array}{l}\text { Dilewatkan pada air } \\
\text { saja }\end{array}$ \\
\hline & $\begin{array}{l}\text { Transfer dari satu tempat } \\
\text { pemrosesan ke tempat } \\
\text { yang lain dengan baskom } \\
\text { tertutup rapat dengan } \\
\text { plastik foil }\end{array}$ & $\begin{array}{l}\text { Transfer dari satu } \\
\text { tempat pemrosesan } \\
\text { ke tempat yang lain } \\
\text { dengan baskom } \\
\text { tertutup }\end{array}$ \\
\hline
\end{tabular}




\begin{tabular}{|c|c|c|}
\hline & $\begin{array}{l}\text { Kewajiban mencuci } \\
\text { tangan dan kaki dengan } \\
\text { sabun sebelum masuk } \\
\text { area kerja }\end{array}$ & $\begin{array}{l}\text { Kewajiban mencuci } \\
\text { tangan dan sebelum } \\
\text { masuk area kerja }\end{array}$ \\
\hline & $\begin{array}{l}\text { Pembuatan SOP } \\
\text { Kebersihan Bahan }\end{array}$ & $\begin{array}{l}\text { Memastikan semua } \\
\text { proses bersih }\end{array}$ \\
\hline \multirow{3}{*}{ Kontrol Lingkungan } & $\begin{array}{l}\text { Penerapan piket } \\
\text { kebersihan yang meliputi } \\
\text { kebersihan dinding, atap, } \\
\text { dan lantai setiap hari }\end{array}$ & $\begin{array}{l}\text { Penerapan piket } \\
\text { kebersihan yang } \\
\text { meliputi kebersihan } \\
\text { dinding, atap, dan } \\
\text { lantai setiap minggu }\end{array}$ \\
\hline & $\begin{array}{l}\text { Piket harian menjaga } \\
\text { binatang seperti burung, } \\
\text { kucing, ayam, kambing, } \\
\text { kecoa, dan binatang } \\
\text { lainnya masuk daerah } \\
\text { produksi }\end{array}$ & $\begin{array}{l}\text { Cukup memastikan } \\
\text { area bersih dari sisa- } \\
\text { sia binatang seperti } \\
\text { kotoran, bulu } \\
\text { binatang, dan sisa } \\
\text { serangga }\end{array}$ \\
\hline & $\begin{array}{l}\text { Penjagaan alur kerja } \\
\text { sesuai dengan alur kerja }\end{array}$ & $\begin{array}{l}\text { Boleh pindah dari } \\
\text { satu tempat ke } \\
\text { tempat lain asal } \\
\text { kondisi bersih }\end{array}$ \\
\hline \multirow{3}{*}{ Sistem Pengemasan } & $\begin{array}{l}\text { Memastikan storage yang } \\
\text { baik dengan toples besar, } \\
\text { sebelum ditutup dilapisi } \\
\text { plastic foil }\end{array}$ & $\begin{array}{l}\text { Dengan plastik besar, } \\
\text { diikat rapat }\end{array}$ \\
\hline & $\begin{array}{l}\text { Memastikan kebersihan } \\
\text { pelaku pengemasan dan } \\
\text { menggunakan pakaian } \\
\text { pelindung standar kerja }\end{array}$ & $\begin{array}{l}\text { Memastikan } \\
\text { pengemas dan } \\
\text { pakaiannya bersih } \\
\text { dan sehat }\end{array}$ \\
\hline & $\begin{array}{l}\text { Mengecek kemasan retail } \\
\text { sudah tersegel rapat } \\
\text { kedap udara dan } \\
\text { dilengkapi label yang } \\
\text { disyaratkan dalam } \\
\text { peraturan BPOM no } 31 \\
\text { tahun } 2018\end{array}$ & $\begin{array}{l}\text { Mengecek kemasan } \\
\text { retail sudah tersegel } \\
\text { rapat kedap udara }\end{array}$ \\
\hline Sistem Penggorengan & $\begin{array}{l}\text { Minyak goreng diganti } \\
\text { setiap habis produksi }\end{array}$ & $\begin{array}{l}\text { Minyak goreng } \\
\text { diganti setiap dua } \\
\text { hari sekali, tapi } \\
\text { dipastikan penirisan } \\
\text { minyak lebih lama }\end{array}$ \\
\hline \multicolumn{3}{|c|}{$\begin{array}{l}\text { Sumber air dan saluran pembuangannya sudah baik di UKM Keripik } \\
\text { Semat Desa Tenjo. Tempat cuci tangan dan kaki, jamban, serta tempat } \\
\text { pencucian bahan sudah terpisah. Prosedur cuci tangan dan kaki wajib } \\
\text { dilakukan sebelum bekerja (Gambar 4.). Pencucian bahan sebelum dimasak } \\
\text { dilakukan di wastafel (Nomor urut 4. Pada Gambar 3.). Proses pencucian } \\
\text { dilakukan sekaligus dengan proses sorting untuk memastikan bahan baku } \\
\text { aman dan tidak terjangkit penyakit. Karena bahan baku keripik diambil dari } \\
\text { tanah, harus dipastikan bahwa sisa-sisa tanah benar-benar telah tercuci bersih } \\
\text { SOP cuci "Basuh- usap (3x)-basuh" diterapkan untuk memastikan bahan baku } \\
\text { benar-benar bersih dari tanah dan sisa-sisa pertanian lainnya (Gambar 9.) } \\
\text { Untuk memastikan kebersihan bahan baku. Keamanan pekerja juga }\end{array}$} \\
\hline
\end{tabular}


diperhatikan dengan menyediakan APD berupa celemek, masker, dan sarung tangan (Gambar 8.). UKM Keripik Semat Desa Tenjo menerapkan SOP alur kebersihan bahan dan SOP alur produksi (Gambar 10 dan 11.). Langkahlangkah ini dilakukan untuk menjaga higienitas dan keamanan pekerja beserta bahan baku. SOP tersebut juga berfungsi sebagai rujukan program dan pemeliharaan hygiene sanitasi di UKM Semat. Fajriansyah (2016) menyebutkan, dalam produksi usaha roti di Aceh, baru 43\% saja pekerjanya yang menerapkan prisnsip higienitas dan sanitasi. Tari dkk (2015) menyebutkan bahwa kebersihan dan higienitas fasilitas dan karyawan sangat berpengaruh pada proses pengembangan UKM Tempe di Wonogiri.

Pencatatan di UKM Keripik Semat masih terbatas pada pencatatan laba rugi, jumlah produksi, tempat pembelian bahan, dan penjualan saja. Pengontrolan untuk kinerja dalam bidang kebersihan masih bersifat oral dengan memberi peringatan langsung kepada petugas piket yang bertanggung jawab. Storage dan tempat pengolahan lainnya masih belum terpisah, namun sudah disediakan rak khusus untuk penyimpanan sementara kemasan besar/glondongan dan kemasan retail. APD yang digunakan oleh pekerja adalah APD standar. Pemindahan keripik ke dalam kemasan retail dilakukan menggunakan sarung tangan plastik untuk menjaga perpindahan kontaminan dari tangan karyawan ke produk makanan. Kemasan retail merupakan plastic pouch zip lock dengan heat seal (Gambar 13.). Produk yang rusak diambil dan tidak dilepaskan ke pasar. Prosedur yang disusun diharapkan dapat digunakan untuk menjaga kualitas produk UKM Semat Desa Tenjo. Pemasakan sebaiknya menggunakan minyak satu kali pakai untuk menghindari hazard berupa kolesterol dan radikal bebas.

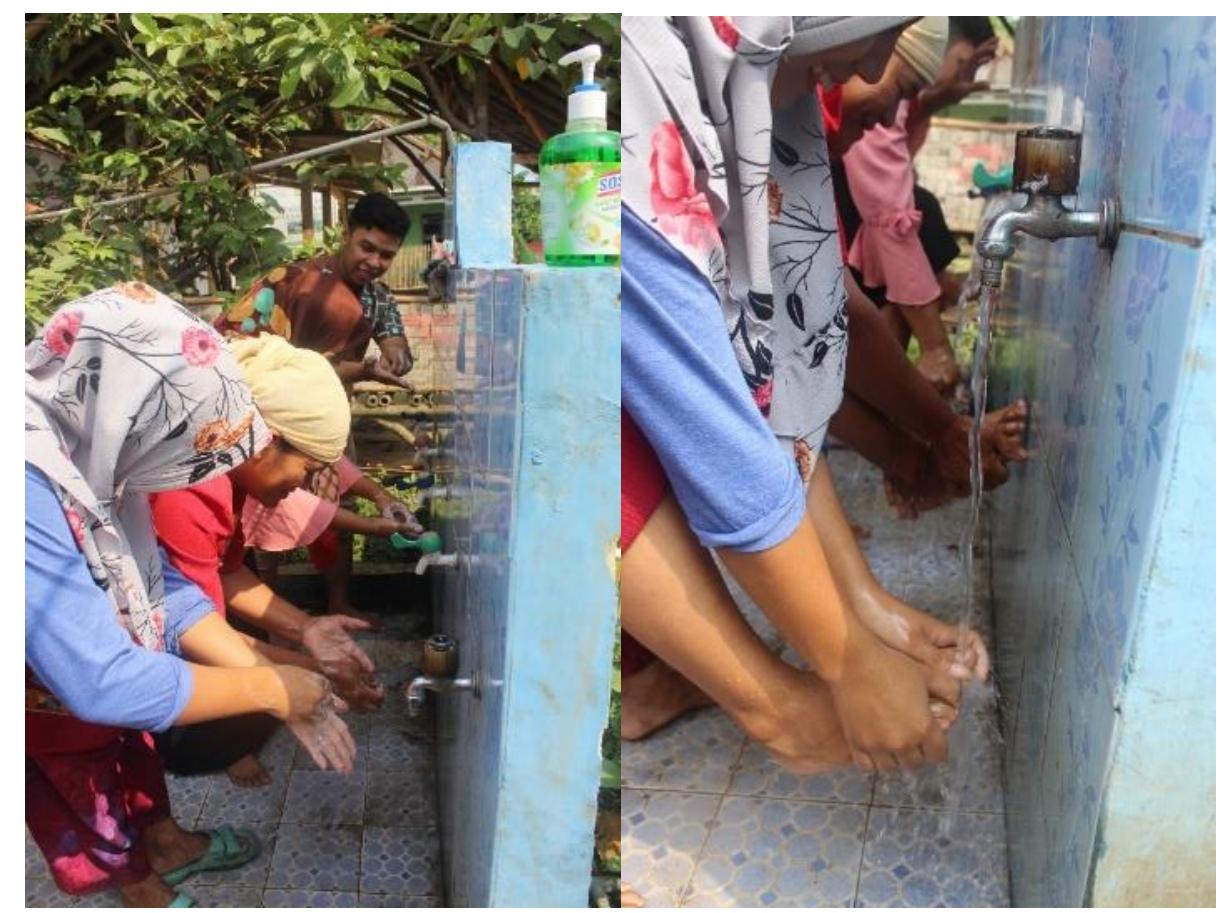

Gambar 4. Rutinitas Pekerja di UKM Keripik Semat Desa Tenjo untuk Cuci Tangan dan Kaki Sebelum Masuk Area Produksi 


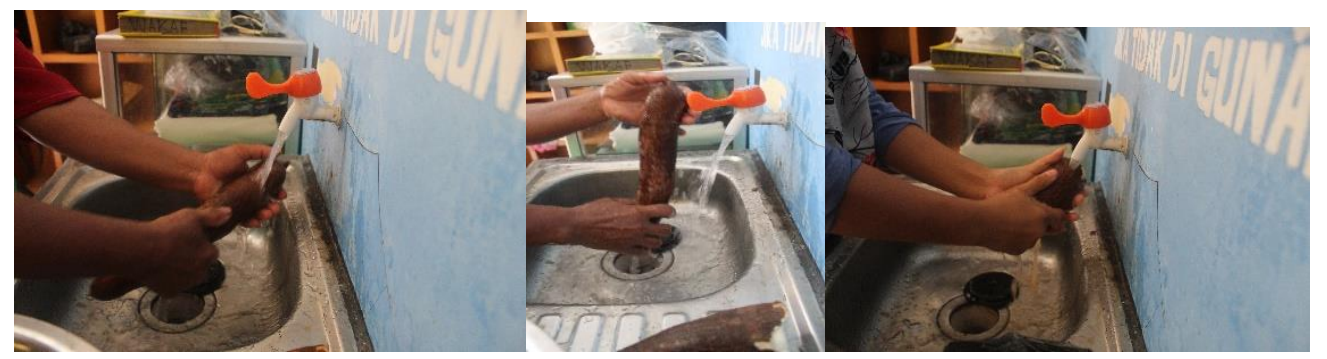

Gambar 5. SOP Basuh-Usap-Basuh Pada Proses Pencucian Bahan Baku

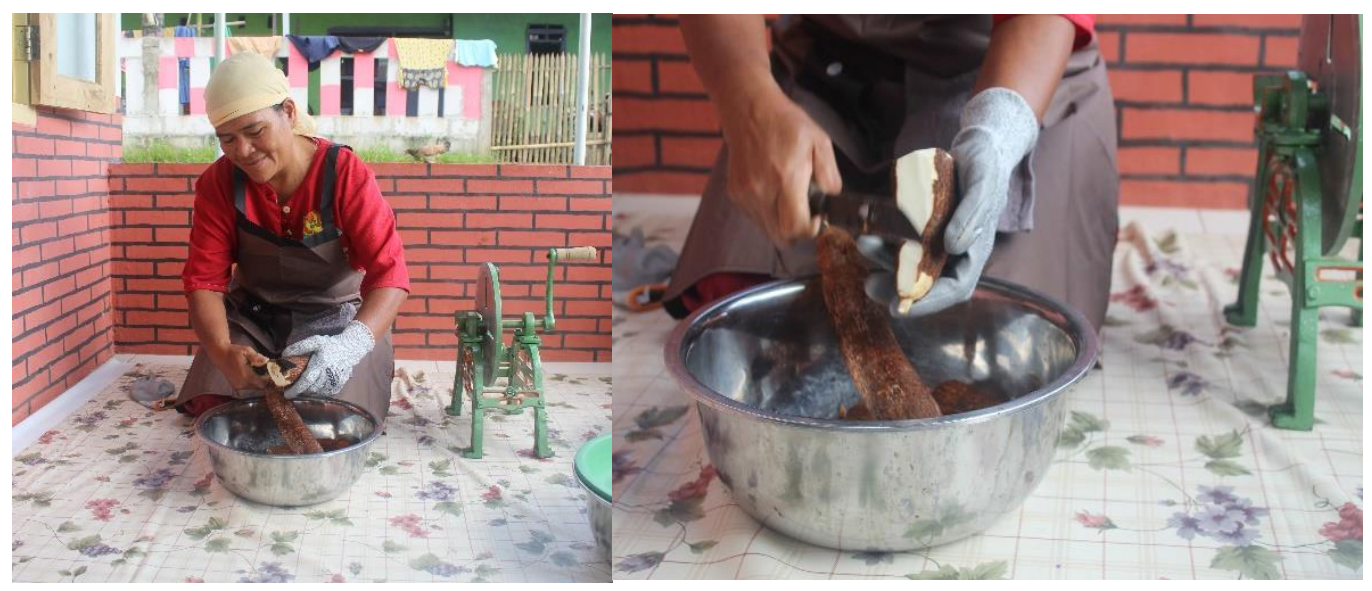

Gambar 6. SOP Keselamatan Kerja Saat Pengupaasan

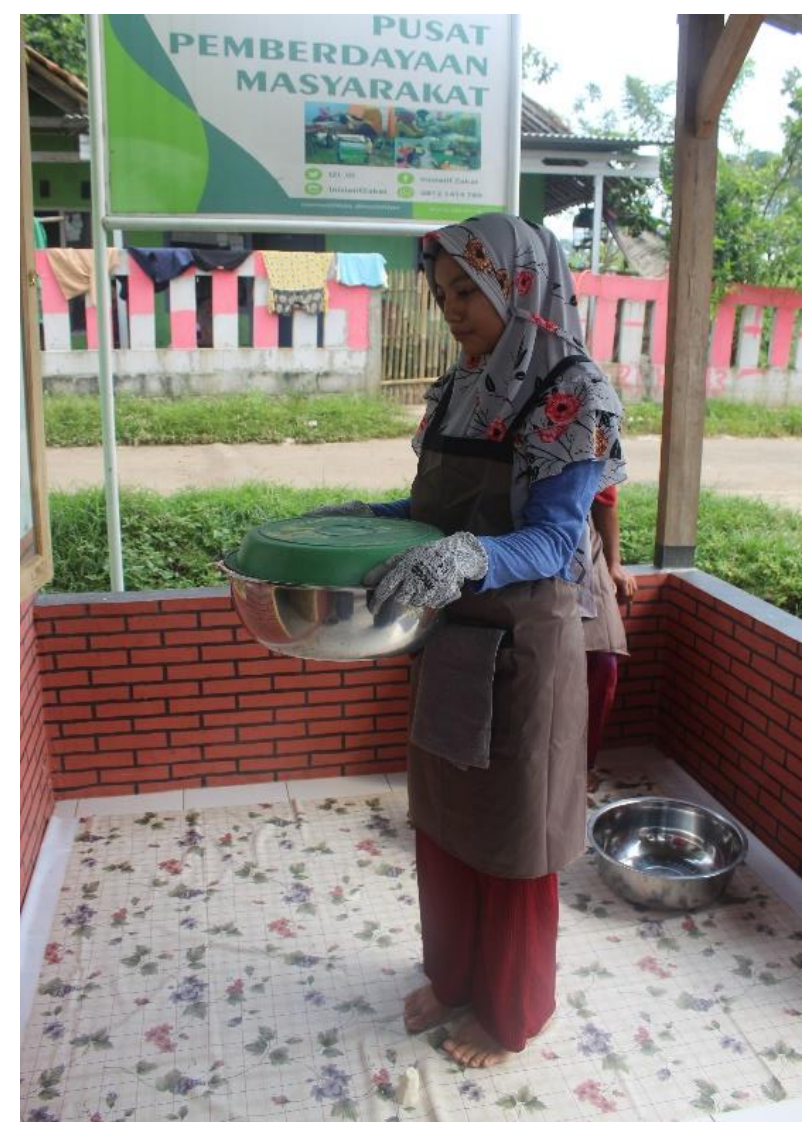

Gambar 7. SOP Transfer dari Satu Tempat Pemrosesan ke Tempat Pemrosesan yang Lain 


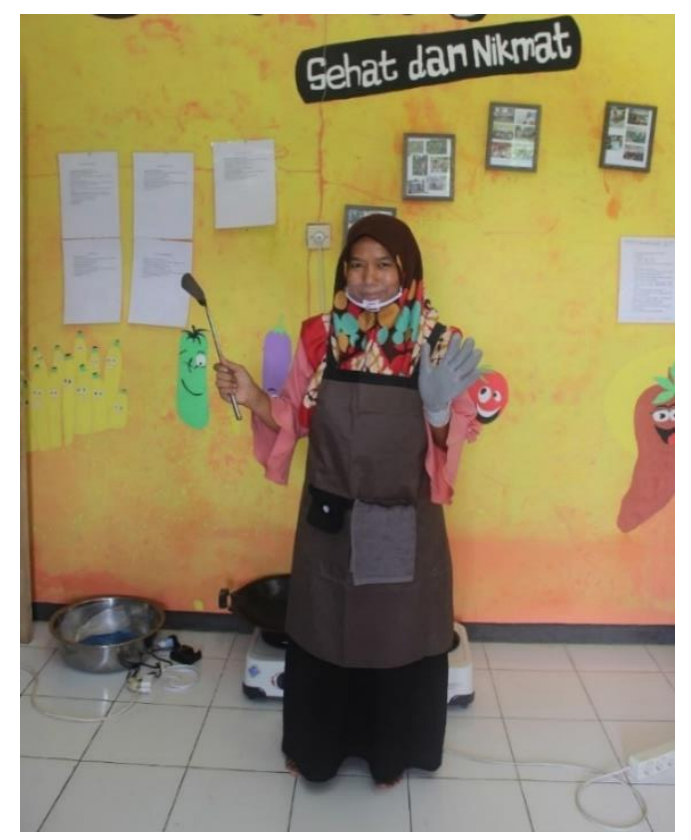

Gambar 8. SOP Kelengkapan Alat Keselamatan Kerja Ketika Proses Pemasakan

\section{PROSEDUR PENCUCIAN BAHAN BAKU}

\section{Contoh: Umbi Singkong}

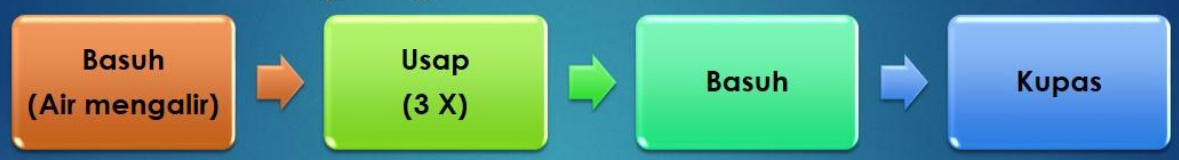

Gambar 9. SOP Pencucian Bahan Baku

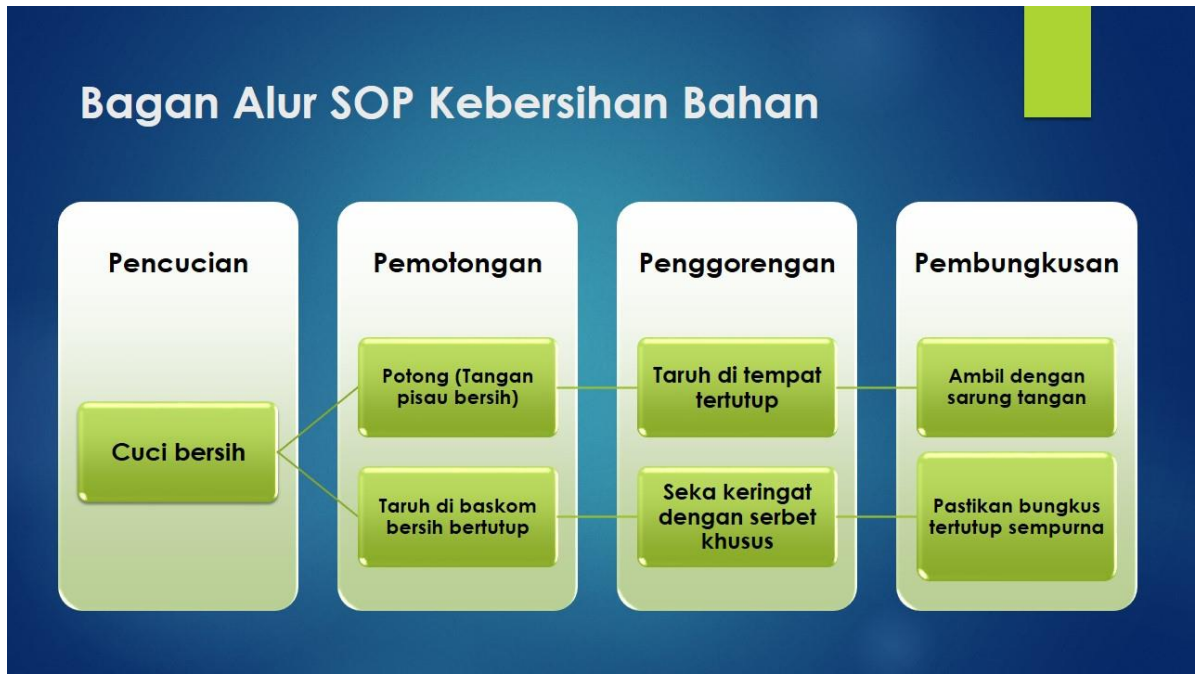

Gambar 10. SOP Alur Kebersihan Bahan 


\section{JAGA!! > Alur Kerja}
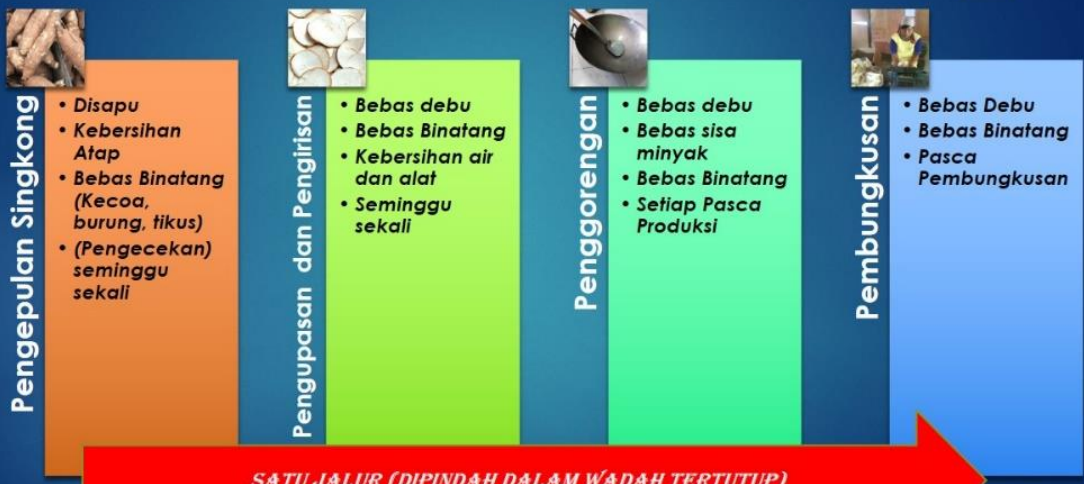

SATU JALUR (DIPLDAH DALAM WADAH TERTUTUP)

Gambar 11. SOP Alur Produksi UKM Keripik Semat Desa Tenjo

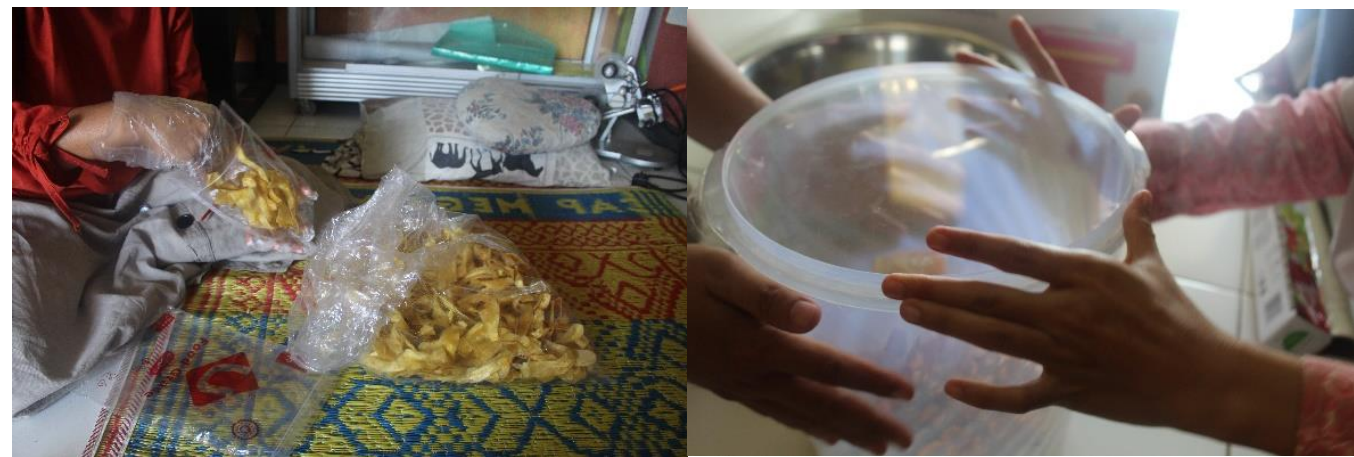

Gambar 12. SOP Pengemasan dan Storage Keripik Semat Desa Tenjo

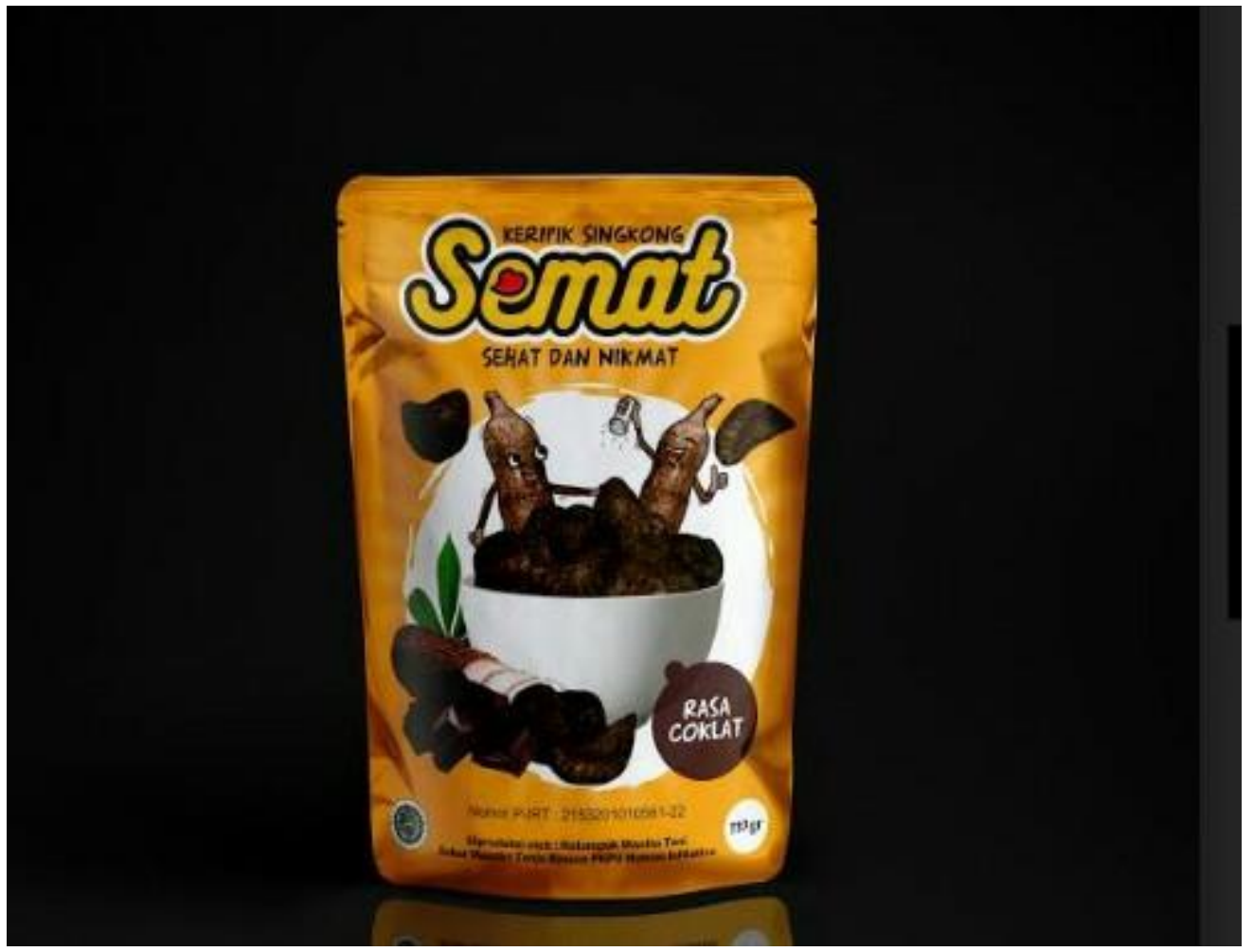

Gambar 13. Kemasan Retail Keripik Singkong Semat 


\section{KESIMPULAN}

Penerapan GMP di UKM Keripik Tenjo baru memenuhi syarat-syarat CPPBIRT pada level 4 (PIRT). Untuk menjaga kualitas diperlukan kontrol yang lebih baik terutama dalam hal kontrol peralatan, peningkatan nilai praktek personal, penerapan prosedur penjagaan kebersihan bahan, kontrol lingkungan, pengontrolan penggorengan, pengemasan, dan storage. SOP yang disusun diharapkan dapat digunakan untuk menjaga kualitas produk keripik Semat Desa Tenjo bahkan meningkatkannya.

\section{DAFTAR PUSTAKA}

Alum, E.A., Urom, S.M.O.C. and Ben, C.M.A., 2016. Microbiological Contamination of Food: The Mechanisms, Impacts and Prevention. Int. J. Sci. Technol. Res, Vol 5 (3) : 65-78.

American Spice Trade Association., 2014. HACCP Guides for Spices and Seasonings. American Spice Trade Association (ASTA), Inc.

Anggraini, T. and Yudhastuti, R., 2014. Penerapan Good Manufacturing Practicess pada Industri Rumah Tangga Kerupuk Teripang di Sukolilo Surabaya. Jurnal Kesehatan Lingkungan, Vol 7 (2) : 148-158.

BPOM, 2012. Tata Cara Pemeriksaan Sarana Produksi Pangan Industri Rumah Tangga. PERATURAN KEPALA BADAN PENGAWAS OBAT DAN MAKANAN REPUBLIK INDONESIA NOMOR HK.03.1.23.04.12.2207 TAHUN 2012.

BPOM, 2016. Laporan $\quad$ Tahunan https://www.pom.go.id/new/admin/dat/20171127/laptah2016.pdf

BPOM, 2017. Laporan $\quad$ Tahunan 2017. https://www.pom.go.id/new/admin/dat/20180710/Laporan\%20Tahunan\% 20BPOM\%202017.pdf

Chukwu, O., 2009. Impacts Of Food Processing Industry On Some Environmental Health And Safety Factors. Caspian Journal of Environmental Sciences, Vol 7 (1) : 37-44.

CODEX ALIMENTARIUS, 2014. Code of Hygiene Practice for Spices and Dried Aromatic Herbs. Food and Agriculture Organisation of the United Nation and World Health Organisation.

Cuihua, Q., 2014. Establish Central Kitchen under HACCP Control in Food and Beverage Industry to Ensure Food Safety And Hygiene. SHS Web Conference. Vol. 6 No. 03005.

Dewi, A.R.R., 2017. Strategi Peningkatan Mutu dan Keamanan Pangan Olahan Pertanian Melalui Penerapan Good Manufacturing Practices Pada Umkm Pangan Berdaya Saing Di Kota Bandung. Thesis. Sekolah Pasca Sarjana. Institut Pertanian Bogor.

Dewi, A.R.R., 2017. Strategi Peningkatan Mutu Dan Keamanan Panganolahan Pertanian Melalui Penerapan Good Manufacturing Practices Pada Umkm Pangan Berdaya Saing Di Kota Bandung. Repository IPB. https: / / repository.ipb.ac.id/jspui/bitstream/123456789/91395/1/2017arr. pdf

Dewi, D.C. and Pramudya Kurnia, S.T.P., 2017. Evaluasi Sarana Produksi Pangan Industri Rumah Tangga Pangan (IRT) Kerupuk Ikan Tenggiri Di 
Kecamatan Cilacap Selatan Kabupaten Cilacap. Desertasi. Universitas Muhammadiyah Surakarta.

Fajriansyah, 2016. Hygiene dan Sanitasi Pengolahan Roti pada Pabrik Roti Paten

Bakery. AcTion: Aceh Nutrition Journal, Vol. 1 (2) : 116-120.

Food and Agriculture Organisation (FAO), 2017. Food Handler Manual: Instructor. Published by FAO, WHO, and Pan America Helath Organisation.

Food Safety Center of Manitoba, 2018. Facsheet \#15: Good Manufacturing Practices (GMP). Food Safety Programe for Processor and Distributor.

Hanif, A., 2012. Implementasi Peraturan BPOM Nomor Hk.03.1.23.04.12.2205 Tahun 2012 Tentang Pedoman Pemberian Sertifikat Produksi Pangan Industri Rumah Tangga (P-IRT) Di Kabupaten Pemalang. Skripsi. Universitas Negeri Semarang.

Hubeis, M and Najib, M., 2014. Manajemen Strategik. Penerbit Elex Media Computindo.

Hubeis, M., Purwanto, B., Dewi, F.R., Widyastuti, A., and Febtyanisa, M., 2014. Strategi Pengembangan Umkm Pangan yang Berdaya Saing di Indonesia. Prosiding Seminar Hasil-Hasil PPM IPB 2015, Vol. 1 : 126-143.

Ingle, P.V., Chatap, V.K. and Bhatia, N.M. 2014. Environmental Control for Parenteral Production. Journal of Pharmaceutical Research and Clinical Practice Vol 4 (3) : 22-32.

Kementerian Koperasi dan UKM, 2017. Perkembangan Data Usaha Mikro, Kecil, Menengah (UMKM) dan Usaha Besar (UB) Tahun 2016-2017. http://www.depkop.go.id/uploads/laporan/1549946778_UMKM\%2020162017\%20rev.pdf

Kennedy, J., Nolan, A., Gibney, S., O'Brien, S., McMahon, M.A.S., McKenzie, K., Healy, B., McDowell, D., Fanning, S. and Wall, P.G., 2011. Deteminants of Cross-Contamination During Home Food Preparation. British Food Journal, Vol. 113 (2) : 280-297.

Menteri Perindustrian Republik Indonesia, 2010. Pedoman Cara Produksi Pangan Olahan yang Baik. Peraturan Menteri Perindustrian RI. Nomor: 75 MIND/PER/7/2010.

Mukantwali, C., Laswai, H., Tiisekwa, B. and Wiehler, S., 2013. Good Manufacturing and Hygienic Practices at Small and Medium Scale Pineapple Processing Enterprises in Rwanda. Compliance of Small and Medium Scale Pineapple Processing Enterprises with National and International Standards in Rwanda. Hal: 51.

Ningsih, R., 2014. Penyuluhan Hygiene Sanitasi Makanan dan Minuman, Serta Kualitas Makanan yang Dijajakan Pedagang di Lingkungan SDN Kota Samarinda. KEMAS: Jurnal Kesehatan Masyarakat, Vol 10 (1) : 64-72.

Nuraida, L., 2008. Keamanan Pangan Industri Usaha Kecil dan Menengah (UKM) Dan Industri Rumah Tangga (IRT) Pangan. Disampaikan pada pra-WNPG (Widyakarya Nasional Pangan dan Gizi) IX. Jakarta, 17 Juni 2008.

Presiden Republik Indonesia, 2004. Keamanan, Mutu dan Gizi Pangan. Peraturan Pemerintah Republik Indonesia Nomor 28 Tahun 2004.

Presiden Republik Indonesia, 2012. Pangan. Undang-Undang Republik Indonesia Nomor 18 Tahun 2012 . 
Sutton, S., 2010. The Environmental Monitoring Program in A GMP Environment. Journal of GXP Compliance, Vol 14 (3) : 22-30.

Tari, A.I.N., Wiharti, T. and Hartati, S.S., 2015. Pengembangan Usaha Tempe Dan Keripik Tempe Untuk Ukm Jatisrono Wonogiri. SEMAR (Jurnal Ilmu Pengetahuan, Teknologi, dan Seni bagi Masyarakat), Vol 4 (1) : 72-83.

WHO, 2015. World Health Day 2015: Food Safety. https: / / www.pom.go.id/new/admin/dat/20171127/laptah2016.pdf

Yadav, S. 2018. Edible Oil Adulterations: Current Issues, Detection Techniques, and Health Hazards. IJCS, Vol 6 (2) : 1393-1397.

Yang, M.G.M., Hong, P. and Modi, S.B., 2011. Impact Of Lean Manufacturing And Environmental Management On Business Performance: An Empirical Study Of Manufacturing Firms. International Journal of Production Economics Vol. 129 (20:251-261.

Yulianti, M.D. and Mustarichie, R., 2017. Tata Cara Registrasi Untuk Pangan Olahan Industri Rumah Tangga (PIRT) Dan Makanan Dalam Negeri (MD) Dalam Rangka Peningkatan Produk Yang Aman Dan Bermutu Di Bandung Jawa Barat. Farmaka, Vol 15 (3) : 57-64. 